\title{
Multivariate Statistical Analysis of Heavy Metals and other Hydro Chemical Characteristics in Industrially Polluted Groundwater Resources of Mettur, India
}

\author{
R. JAYAKUMAR, S. DHANAKUMAR, K. KALAISELVI and M. PALANIVEL ${ }^{*}$ \\ PG and Research Department of Environmental Science, PSG College of Arts and Science, \\ Coimbatore-641 014, India \\ jaimscche@gmail.com
}

Received 20 May 2015 / Accepted 4 June 2015

\begin{abstract}
Mettur an industrial town is located in Salem district of Tamil Nadu, India. The major industries, namely; Chemplast, The Madras Aluminum Company and Mettur Thermal Power Plant are located in Mettur town. In addition, several chemical industries are situated on the banks of the River Cauvery as part of Small Industries Development Corporation (SIDCO) industrial estate. With this background, the present study attempts to investigate the usefulness of multivariate statistical analysis for the assessment of complex data sets to get better information about an influence of various parameters on groundwater chemistry and heavy metal concentrations. Groundwater samples were collected during pre-monsoon (June 2013) and post-monsoon (February 2014) seasons and analysed for heavy metals and other hydro chemical characteristics. The results of the multivariate statistical analysis show that the sampling site have different characteristics in terms of heavy metals studied and indicate that each region receives pollution from different sources. The high level of some of the heavy metals and hydrochemical recorded in certain pollution packets ultimately implies an alarming situation in the viewpoint of health risk. The notable differences in the quality of groundwater between the sampling sites indicate possible land use influences.
\end{abstract}

Keywords: Groundwater, Pollution, Multivariate statistics, Industrial pollution, Agrochemicals

\section{Introduction}

Groundwater resources are highly crucial to a range of human needs such as domestic, agricultural and industrial purposes. The consumption rate of groundwater is increasing gradually in the areas where surface water sources are not enough to meet the demands ${ }^{1}$. According to recent reports, several states in India are dependent on groundwater to meet out their $90 \%$ of domestic and agricultural needs ${ }^{2-3}$. Dispose of untreated/partially treated industrial effluents, urban wastes and agrochemicals (fertilizers, herbicides and pesticides) are the primary causes of groundwater contamination ${ }^{4}$. Although the industrial sector only accounts for three per cent of the annual water withdrawals in India, it causes severe water pollution in most of the freshwater and groundwater resources. Among the pollutants, heavy 
metals are ubiquitous in nature and gain scientific interest due to its unique characteristics such as high reactivity, lithophilic nature, toxicity and non-biodegradability ${ }^{5}$. The term "heavy metal" refers to any metallic chemical element that has a relatively high density and is toxic at low concentrations.

Decline of water quality in general and groundwater in particular is of great concern in India. Studies on groundwater quality monitoring would help to identify safe zones for drinking water and provide solution to the quality problems in groundwater by means of hydrogeological and geochemical data. Although statistical approaches are recommended for its usefulness in the monitoring of groundwater resources and its related pollution studies have not been utilized much. Multivariate statistical approach allows deriving simple relations which are much useful in characterizing and getting first hand information of the groundwater system than actually going through complex methodologies.

\section{Experimental}

The study area Mettur is one among the important industrial centres of Tamil Nadu. It is located at $11^{\circ} 45^{\prime}$ of the Northern Latitudes and $77^{\circ} 45^{\prime}$ of the Eastern Longitude (Figure 1). It has its uniqueness in the distribution of a variety of physiographic features ranging from extensive hilly areas to undulating plains. Three largest industries namely Chemplast, Madras Aluminum Company and the Mettur Thermal Power Plant are located in Mettur town. In addition, numerous chemical industries are located on the banks of the River Cauvery in Mettur as a part of Small Scale Industries Development Corporation (SIDCO) Industrial Estate. In this background, the present study attempts to investigate the heavy metals and other hydro chemical characteristics in groundwater samples in the Mettur industrial region using multivariate data analysis.



Figure 1. Sampling location and map of the Mettur industrial area

\section{Sampling and Methodology}

Groundwater samples were collected in acid washed polythene bottles from 49 stations during pre-monsoon (June 2013) and post-monsoon season (February 2014) in Mettur 
industrial area. The sampling locations are shown in Figure 1. Water samples were analyzed for $\mathrm{pH}$, Electrical Conductivity (EC), Total Dissolved Solids (TDS), total hardness, chloride $(\mathrm{Cl})$, alkalinity, calcium $(\mathrm{Ca})$, magnesium $(\mathrm{Mg})$, sodium $(\mathrm{Na})$, potassium $(\mathrm{K})$, nitrite $\left(\mathrm{NO}_{2}\right)$ nitrates $\left(\mathrm{NO}_{3}\right)$, sulfate $\left(\mathrm{SO}_{4}\right)$, phosphate $\left(\mathrm{PO}_{4}\right)$ and fluoride $(\mathrm{F})$ as per standard methods ${ }^{6}$.
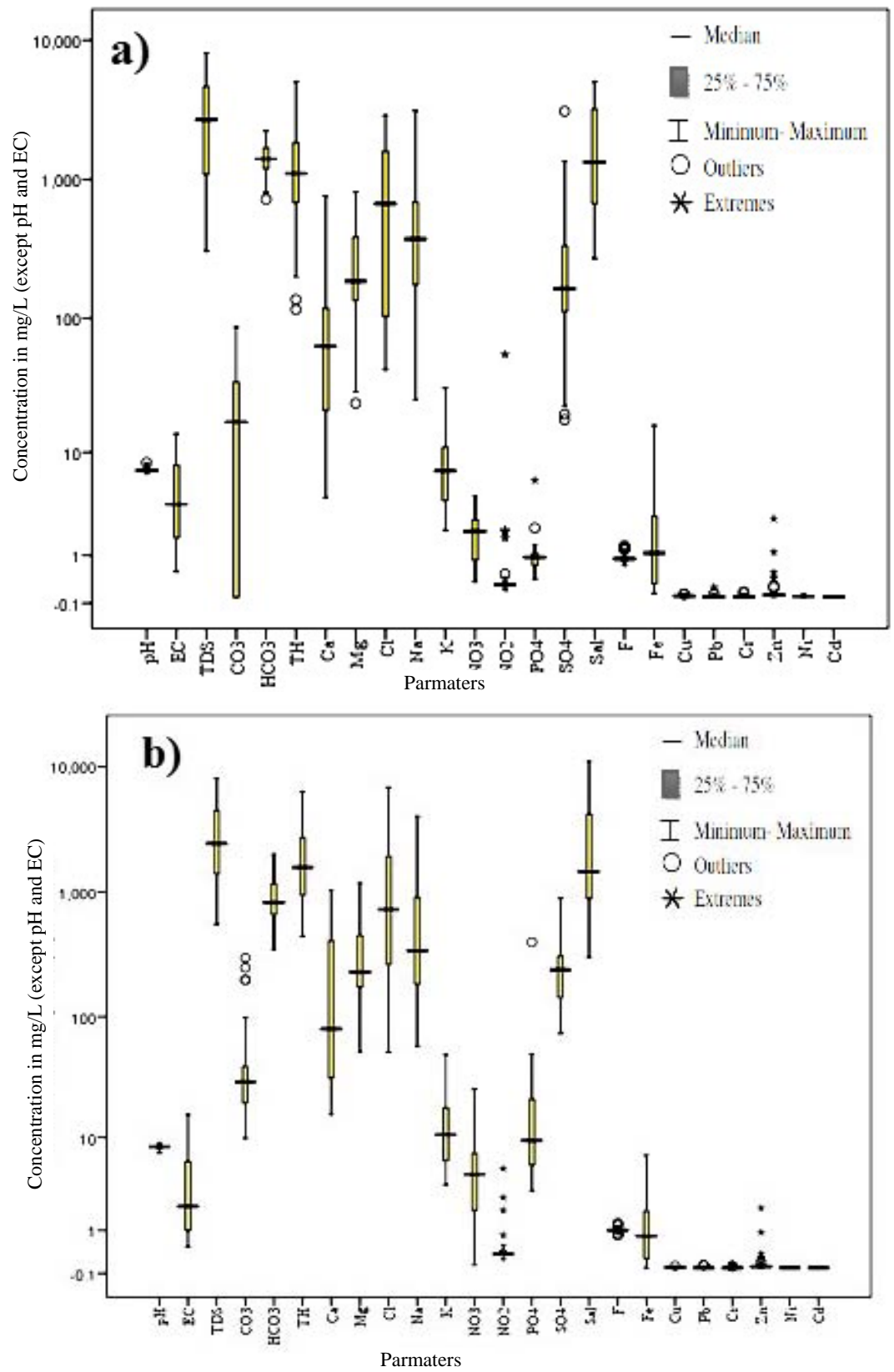

Figure 2. Hydrochemical characteristics of groundwater during; a) pre-monsoon and b) post-monsoon season 
For the heavy metals analysis, water samples $(50 \mathrm{~mL})$ were subjected to concentrated $\mathrm{HNO}_{3}$ digestion until the solution became transparent and atomic absorption spectrophotometrically analyzed (Shimadzu AA6300). The results obtained were subjected to statistical analysis, such as paired T-test, cluster analysis and factor analysis using Statistical Package for Social Scientists (SPSS) $16^{\text {th }}$ version.

\section{Results and Discussion}

\section{Physical properties of groundwater samples}

Groundwater qualities of forty-nine samples representing Mettur industrial area during premonsoon and post-monsoon seasons are given in Figure 2. The $\mathrm{pH}$ of the groundwater samples were observed as slightly acidic to alkaline nature (6.67-8.90). Electrical conductivity (EC) level of the samples ranged between 0.48 and $15.7 \mathrm{mS} / \mathrm{cm}$. Mean level of total dissolved solids (TDS) was figured as 2896 and $2977 \mathrm{mg} / \mathrm{L}$ in pre-monsoon and postmonsoon season, respectively. Notably higher level of EC and TDS recorded in postmonsoon season samples implies monsoonal influenced leaching of industrial effluents and agrochemicals in the study area.

\section{Major ions concentration}

Concentration of calcium (Ca), magnesium (Mg), sodium $(\mathrm{Na})$ and potassium $(\mathrm{K})$ were figured in the range of $4.2-1044 \mathrm{mg} / \mathrm{L}, 25.3-1166.7 \mathrm{mg} / \mathrm{L}, 25.3-4004 \mathrm{mg} / \mathrm{L}$ and $2.02-49.4$ $\mathrm{mg} / \mathrm{L}$, respectively. Mg content was considerably higher than other cations (Ca and $\mathrm{K}$ ) was probably due to the leaching of effluents from nearby agrochemical industry. Concentration of cation was observed in the order of $\mathrm{Na}>\mathrm{Mg}>\mathrm{Ca}>\mathrm{K}$, whereas anion level was noted as and $\mathrm{HCO}_{3}>\mathrm{Cl}>\mathrm{SO}_{4}>\mathrm{CO}_{3}>\mathrm{NO}_{3}>\mathrm{NO}_{2}>\mathrm{PO}_{4}$ and $\mathrm{Cl}>\mathrm{HCO}_{3}>\mathrm{SO}_{4}$ $>\mathrm{CO}_{3}>\mathrm{PO}_{4}>\mathrm{NO}_{3}>\mathrm{NO}_{2}$ in pre-monsoon and post-monsoon, respectively. During postmonsoon season, total hardness content of all water samples exceeded the permissible limit of $300 \mathrm{mg} / \mathrm{L}$.

Mean level of chloride was figured as 852 and $1188 \mathrm{mg} / \mathrm{L}$ in pre-monsoon and postmonsoon season, respectively. In general, notably very high concentration of $\mathrm{Cl}$ recorded in few locations (G19, G21 and G23) probably contributed by leaching of industrial effluents in the vicinity, as these sample locations are very close to a cluster of industries such as Chemplast, Malco and etc., indicates suspected groundwater contamination due to industrial effluents. Supportively, the study area is underlined by silicate minerals which are known for a lesser amount of chloride thus natural enrichment of chloride in this region is trace or negligible ${ }^{7}$.

Phosphate $\left(\mathrm{PO}_{4}\right)$ content in $70 \%$ of sampling sites in pre-monsoon and all the sampling sites in post-monsoon exceeded the permissible limit $(0.1 \mathrm{mg} / \mathrm{L})$ of US Public Health Standards ${ }^{8}$. Considerably higher concentration of $\mathrm{PO}_{4}$ was recorded during post-monsoon shows notable high $\mathrm{PO}_{4}$ input from manmade sources such as discharge of untreated or partially treated industrial effluents and municipal sewage in addition to agrochemical leaching. The level of Sulphate $\left(\mathrm{SO}_{4}\right)$ falls in the range from 17.8 to $3090 \mathrm{mg} / \mathrm{L}$ and 73.2 to $893.2 \mathrm{mg} / \mathrm{L}$ in pre-monsoon and post-monsoon, respectively. Fluoride content in all samples falls $(0.7-1.35 \mathrm{mg} / \mathrm{L})$ within the optimum concentration of $1.5 \mathrm{mg} / \mathrm{L}$, as recommended by WHO. Correlation analysis shows strong positive relationship between EC and TDS with $\mathrm{Na}, \mathrm{Ca}, \mathrm{Mg}, \mathrm{HCO}_{3}, \mathrm{Cl}$ and total hardness implies these elements contributes in ionic load of the groundwater (Table 1). 
Table 1. Correlation matrix for hydro-chemical characteristics

\begin{tabular}{|c|c|c|c|c|c|c|c|c|c|c|c|c|c|c|c|c|c|}
\hline & $\mathrm{pH}$ & EC & TDS & $\mathrm{CO}_{3}$ & $\mathrm{HCO}_{3}$ & TH & $\mathrm{Ca}$ & $\overline{M g}$ & $\mathrm{Cl}$ & $\mathrm{Na}$ & $\overline{\mathbf{K}}$ & $\mathrm{NO}_{3}$ & $\mathrm{NO}_{2}$ & $\mathrm{PO}_{4}$ & $\mathrm{SO}_{4}$ & Sal & $\mathbf{F}$ \\
\hline \multicolumn{3}{|c|}{ a) Pre-Monsoon } & $\mathrm{mg} / \mathrm{L}$ & $\mathrm{mg} / \mathrm{L}$ & $\mathrm{mg} / \mathrm{L}$ & $\mathrm{mg} / \mathrm{l}$ & $\mathrm{L} \mathrm{mg/L}$ & $\mathrm{mg} / \mathrm{L}$ & $\mathrm{mg} / \mathrm{L}$ & $\mathrm{mg} / \mathrm{L} \mathrm{n}$ & $\mathrm{mg} / \mathrm{L} \mathrm{m}$ & $\mathrm{ng} / \mathrm{L} \mathrm{n}$ & $\mathrm{mg} / \mathrm{L} \quad \mathrm{I}$ & $\mathrm{mg} / \mathrm{L}$ & $\mathrm{mg} / \mathrm{L}$ & $\mathrm{mg} /$ & $\mathrm{L}$ \\
\hline $\mathrm{pH}$ & 1 & & & & & & & & & & & & & & & & \\
\hline $\mathrm{EC}$ & -0.44 & 1 & & & & & & & & & & & & & & & \\
\hline TDS & -0.45 & $0.96^{* \pi *}$ & 1 & & & & & & & & & & & & & & \\
\hline $\mathrm{CO}_{3}$ & $0.90^{* \pi}$ & -0.42 & -0.43 & 1 & & & & & & & & & & & & & \\
\hline $\mathrm{HCO}_{3}$ & -0.41 & $0.53^{\pi *}$ & $0.49^{\pi *}$ & -0.29 & 1 & & & & & & & & & & & & \\
\hline TH & -0.42 & $0.77^{* *}$ & $0.81^{* *}$ & -0.33 & $0.48^{* *}$ & 1 & & & & & & & & & & & \\
\hline Сa & -0.37 & $0.76^{* \pi}$ & $0.75^{* *}$ & -0.32 & 0.23 & $0.68^{* *}$ & 1 & & & & & & & & & & \\
\hline Mg & -0.36 & $0.63^{* \pi}$ & $0.68^{* *}$ & -0.27 & $0.50^{* *}$ & $0.94^{* *}$ & $0.41^{* \pi}$ & 1 & & & & & & & & & \\
\hline $\mathrm{Cl}$ & -0.46 & $0.96^{* \pi}$ & $0.93^{* *}$ & -0.43 & $0.52^{\pi *}$ & $0.77^{* \pi}$ & $0.77^{* \pi}$ & $0.62^{* *}$ & 1 & & & & & & & & \\
\hline $\mathrm{Na}$ & -0.26 & $0.60^{* *}$ & $0.59^{\text {** }}$ & -0.33 & 0.24 & $0.33^{*}$ & $0.53^{* \pi}$ & 0.18 & $0.60^{* \pi}$ & 1 & & & & & & & \\
\hline $\mathrm{K}$ & -0.16 & 0.26 & 0.24 & -0.14 & 0.18 & $0.29^{*}$ & 0.19 & 0.27 & 0.18 & 0.03 & 1 & & & & & & \\
\hline $\mathrm{NO}_{3}$ & -0.05 & $0.40^{* \pi}$ & $0.41^{* \pi *}$ & -0.01 & 0.26 & $0.46^{* \pi}$ & 0.26 & $0.46^{* \pi *}$ & $0.30^{*}$ & 0.20 & 0.24 & 1 & & & & & \\
\hline $\mathrm{NO}_{2}$ & -0.12 & 0.28 & 0.26 & -0.12 & 0.13 & 0.02 & 0.27 & -0.08 & $0.313^{*}$ & 0.12 & 0.14 & -0.02 & 1 & & & & \\
\hline $\mathrm{PO}_{4}$ & 0.09 & -0.07 & -0.11 & 0.16 & -0.02 & -0.09 & -0.1 & -0.07 & -0.1 & -0.09 & -0.08 & -0.02 & -0.01 & 1 & & & \\
\hline $\mathrm{SO}_{4}$ & -0.18 & $0.49^{* \pi}$ & $0.45^{* *}$ & -0.19 & $0.39^{* *}$ & $0.42^{* \pi}$ & 0.21 & $0.43^{* \pi}$ & $0.41^{* \pi}$ & $0.31^{*}$ & $0.41^{* \pi}$ & $0.42^{\pi n}$ & 0.25 & -0.15 & 1 & & \\
\hline Sal & -0.41 & $0.98^{* \pi}$ & $0.94^{* \pi}$ & -0.38 & $0.53^{* \pi}$ & $0.76^{* \pi}$ & $0.73^{* \pi}$ & $0.63^{* *}$ & $0.96{ }^{* \pi}$ & $0.59^{* \pi}$ & 0.27 & $0.40^{* \pi}$ & ${ }^{* \pi} 0.291^{*}$ & * -0.06 & $0.50^{* \pi}$ & 1 & \\
\hline $\mathrm{F}$ & 0.14 & 0.12 & 0.06 & 0.15 & 0.14 & -0.06 & 0.01 & -0.08 & 0.05 & 0.25 & -0.04 & -0.03 & 30.09 & -0.13 & $0.40^{* \pi}$ & 0.11 & 1 \\
\hline \multicolumn{18}{|c|}{ b) Post-Monsoon } \\
\hline $\mathrm{pH}$ & 1 & & & & & & & & & & & & & & & & \\
\hline EC & -0.3 & 1 & & & & & & & & & & & & & & & \\
\hline TDS & -0.17 & $0.74^{* *}$ & 1 & & & & & & & & & & & & & & \\
\hline $\mathrm{CO}_{3}$ & -0.14 & $0.53^{* \pi}$ & $0.65^{* \pi}$ & 1 & & & & & & & & & & & & & \\
\hline $\mathrm{HCO}_{3}$ & -0.20 & $0.34^{*}$ & $0.38^{* *}$ & $0.64^{* *}$ & 1 & & & & & & & & & & & & \\
\hline $\mathrm{TH}$ & -0.25 & $0.66^{* \pi}$ & $0.89^{* \pi}$ & $0.54^{\pi *}$ & $0.34^{*}$ & 1 & & & & & & & & & & & \\
\hline $\mathrm{Ca}$ & -0.31 & $0.85^{* \pi}$ & $0.77^{* \pi}$ & $0.50^{* *}$ & 0.20 & $0.71^{\text {** }}$ & 1 & & & & & & & & & & \\
\hline $\mathrm{Mg}$ & -0.12 & $0.30^{*}$ & $0.68^{* *}$ & $0.39^{* *}$ & $0.33^{*}$ & $0.86^{* *}$ & 0.28 & 1 & & & & & & & & & \\
\hline $\mathrm{Cl}$ & -0.27 & $0.86^{* \pi}$ & $0.73^{\pi *}$ & $0.48^{* *}$ & 0.27 & $0.64^{\pi *}$ & $0.81^{\pi *}$ & $0.30^{*}$ & 1 & & & & & & & & \\
\hline $\mathrm{Na}$ & -0.05 & $0.65^{* *}$ & $0.81^{* *}$ & $0.69^{* *}$ & $0.40^{* *}$ & $0.56^{* *}$ & $0.62^{* *}$ & $0.32^{*}$ & $0.73^{\text {** }}$ & 1 & & & & & & & \\
\hline K & -0.15 & $0.40^{* \pi}$ & $0.41^{\pi *}$ & $0.34^{*}$ & 0.07 & $0.42^{* *}$ & $0.42^{* \pi}$ & 0.27 & $0.29^{*}$ & $0.31^{*}$ & 1 & & & & & & \\
\hline $\mathrm{NO}_{3}$ & 0.20 & 0.04 & -0.10 & -0.13 & -0.08 & -0.08 & -0.06 & -0.07 & 0.06 & -0.14 & -0.08 & 1 & & & & & \\
\hline $\mathrm{NO}_{2}$ & -0.04 & $0.43^{* \pi}$ & $0.42^{\pi \pi}$ & $0.38^{* *}$ & $0.34^{*}$ & $0.47^{* \pi}$ & $0.48^{* *}$ & $0.30^{*}$ & $0.59^{* \pi}$ & $0.50^{* \pi}$ & 0.07 & -0.06 & 1 & & & & \\
\hline $\mathrm{PO}_{4}$ & -0.03 & 0.08 & 0.08 & $0.33^{*}$ & $0.32^{*}$ & 0.05 & 0.01 & 0.06 & -0.11 & -0.03 & 0.06 & 0.03 & -0.07 & 1 & & & \\
\hline $\mathrm{SO}_{4}$ & -0.20 & $0.48^{* \pi}$ & $0.59^{* *}$ & 0.18 & 0.13 & $0.48^{* *}$ & $0.45^{\text {** }}$ & $0.34^{*}$ & $0.53^{* *}$ & $0.60^{* *}$ & $0.34^{*}$ & -0.03 & $0.49^{* \pi}$ & -0.14 & 1 & & \\
\hline Sal & -0.21 & $0.88^{* \pi}$ & $0.76^{* \pi *}$ & $0.42^{* \pi}$ & $0.28^{*}$ & $0.66^{* \pi *}$ & $0.81^{\text {s* }}$ & $0.33^{*}$ & $0.88^{* \pi}$ & $0.75^{* \pi}$ & $0.44^{* \pi *}$ & -0.03 & $0.53^{* \pi}$ & -0.16 & $.64^{* \pi}$ & 1 & \\
\hline $\mathrm{F}$ & -0.06 & 0.07 & 0.02 & 0.08 & 0.20 & 0.02 & -0.02 & 0.04 & -0.01 & 0.04 & 0.08 & -0.08 & 0.06 & 0.09 & 0.11 & 0.02 & 1 \\
\hline
\end{tabular}




\section{Trace elements concentration}

Maximum concentration of $\mathrm{Fe}, \mathrm{Cu}, \mathrm{Cr}, \mathrm{Zn}, \mathrm{Pb}, \mathrm{Ni}$ and $\mathrm{Cd}$ were measured as $13.2 \mathrm{mg} / \mathrm{L}$, $0.05 \mathrm{mg} / \mathrm{L}, 0.1 \mathrm{mg} / \mathrm{L}, 2.68 \mathrm{mg} / \mathrm{L}, 0.18 \mathrm{mg} / \mathrm{L}, 0.04 \mathrm{mg} / \mathrm{L}$ and $0.008 \mathrm{mg} / \mathrm{L}$, respectively. Mean level of the heavy metals in water samples were observed as follows, Pre - monsoon: Fe $>$ $\mathrm{Zn}>\mathrm{Cu}>\mathrm{Cr}>\mathrm{Pb}>\mathrm{Ni}>\mathrm{Cd}$ and Post-monsoon: $\mathrm{Fe}>\mathrm{Zn}>\mathrm{Cu}>\mathrm{Pb}>\mathrm{Cr}>\mathrm{Ni}>\mathrm{Cd}$. Paired T-test yielded significant difference in heavy metals concentration between the seasons studied (Pre-monsoon and post-monsoon). In addition to industrial pollution, $\mathrm{Zn}$ has agricultural origin coming from extensive use of pesticides and fertilizers by the farmers to improve crop yields in the area ${ }^{9}$.

\section{Principle component analysis}

Factor analysis is a multivariate statistical and it attempts to explain the variance of a large set of interrelated variables with smaller set of independent variables ${ }^{10}$. The factor analysis for pre-monsoon data has extracted four factors which explained $61.34 \%$ of the variance in the data set (Figure 3). Factor 1 accounted for $27.46 \%$ of representation with high positive loadings of EC, TDS, TH, Ca, $\mathrm{Mg}, \mathrm{Cl}, \mathrm{NO}_{3}$, Salinity and $\mathrm{SO}_{4}$. This factor loading suggests diverse role of weathering and anthropogenic influences on these parameters ${ }^{11}$. Factor 2 accounted for $14.39 \%$ of the total variance with loadings of $\mathrm{Na}$, $\mathrm{Zn}$ and Ni. Factor 3 explains $10.26 \%$ of total variance with negative loading of $\mathrm{pH}$ and $\mathrm{CO}_{3}$. Factor 4 yielded $9.22 \%$ of total variance with higher loadings of $\mathrm{PO}_{4}, \mathrm{Fe}, \mathrm{Pb}$ and $\mathrm{Cr}$. Agricultural discharge containing residual of pesticides and fertilizers also contains metals also is seen as another important source of nutrients and heavy metal enrichment in groundwater. For example, $\mathrm{Zn}, \mathrm{Cu}$ and Cd level may also relate to fungicide, pesticides and herbicide applications, which usually contain high levels of $\mathrm{Zn}$ salts and $\mathrm{Cu}$ arsenates ${ }^{12-14}$. Notably, some phosphate fertilizers contain potentially toxic elements, including $\mathrm{As}, \mathrm{Cd}, \mathrm{Cr}, \mathrm{Pd}, \mathrm{Hg}, \mathrm{Ni}$, and $\mathrm{V}$ and some pesticides have contained $\mathrm{Cu}$ and $\mathrm{As}$ as part of their formulation ${ }^{15}$. For $\mathrm{Cr}$, inorganic fertilizers were the largest single source followed by sewage sludge.
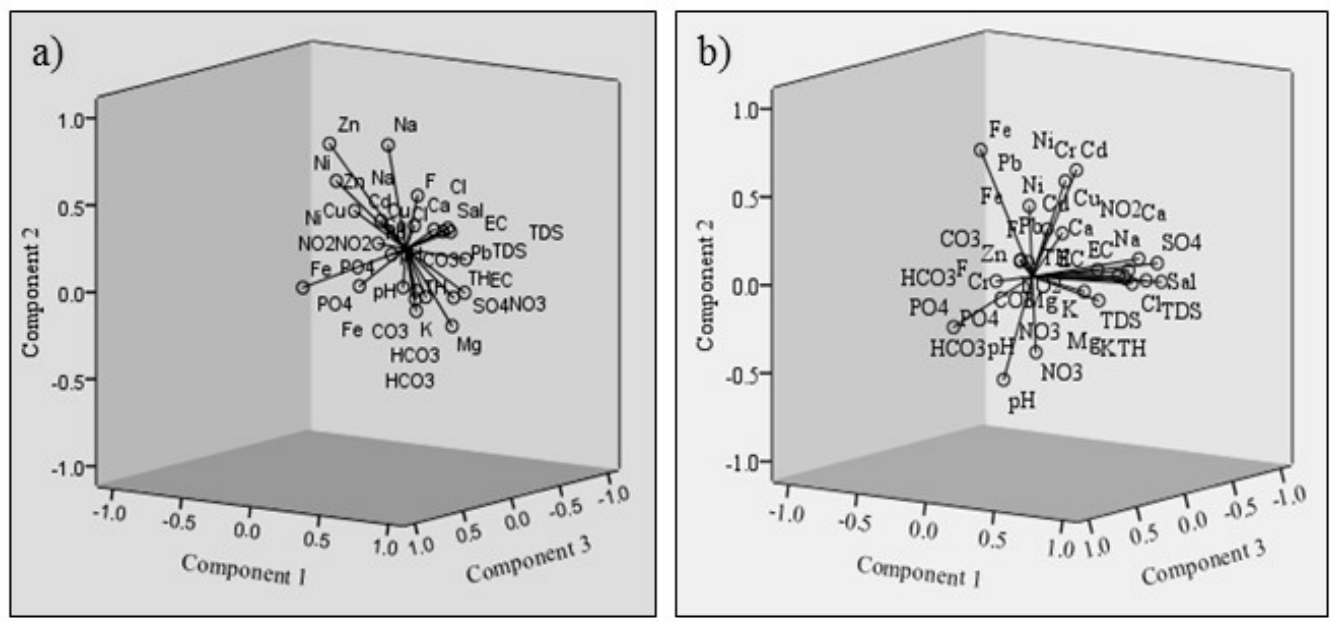

Figure 3. Factor analysis for a) pre-monsoon and b) post-monsoon season

The factor analysis for Post-monsoon data has explained $67.04 \%$ of the total variance with five factors (Figure 3). Factor 1 accounted for $30.12 \%$ of representation with high loadings of EC, TDS, total hardness, $\mathrm{Ca}, \mathrm{Mg}, \mathrm{Cl}, \mathrm{NO}_{2}, \mathrm{SO}_{4}$ and salinity. This factor explains 
complex nature of hydro geochemical processes and its influences factors (natural and anthropogenic) on these parameters. Since, the study area is not known for geogenic sources of $\mathrm{Cl}, \mathrm{Ca}, \mathrm{Mg}$ and $\mathrm{SO}_{4}$ probably these elements may enriched by anthropogenic activities such as industrial effluent disposal and agrochemical application ${ }^{7,16}$. Since, the industrial effluents are known for higher concentration of $\mathrm{Ca}, \mathrm{TDS}, \mathrm{Mg}, \mathrm{Cl}$ and $\mathrm{SO}_{4}$ Factor 2 accounted for $10.44 \%$ of the total variance with loadings of $\mathrm{Fe}$, Ni and $\mathrm{Cd}$. Factor 3 explains $9.79 \%$ of total variance with loadings of $\mathrm{CO}_{3}, \mathrm{HCO}_{3}, \mathrm{PO}_{4}$ and $\mathrm{Cr}$. Factor 4 and 5 contains loadings $\mathrm{Cu}$ and $\mathrm{Zn}$. It reveals notable contributions from agrochemicals runoff. It is worthy to mention that according to recent report the excessive utilization of fertilisers and pesticides for agricultural activities in the study area has resulted in a localised enrichment of $\mathrm{NO}_{3}, \mathrm{PO}_{4}, \mathrm{SO}_{4}, \mathrm{~F}$ and heavy metals in the groundwater resources ${ }^{16}$.
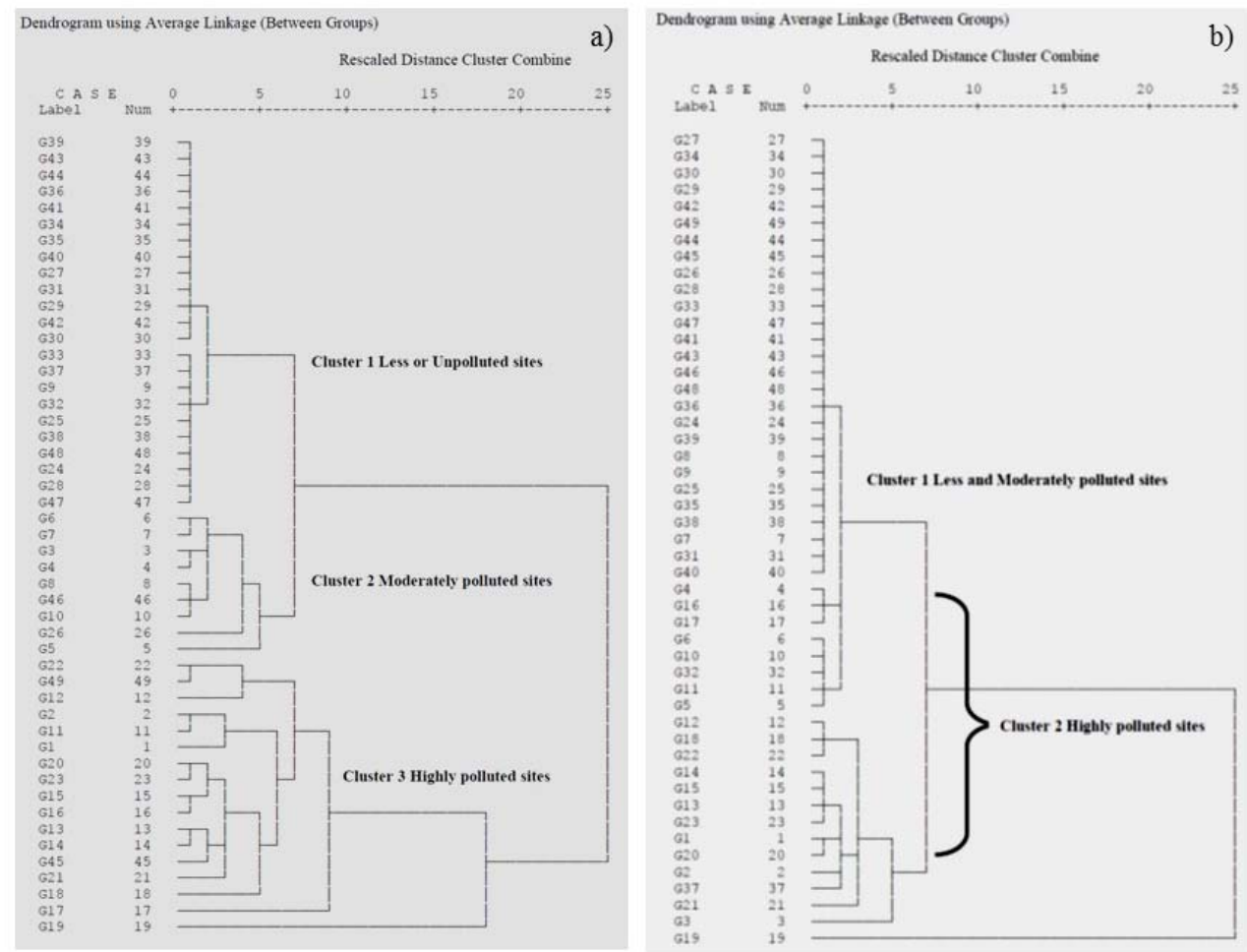

Figure 4. Cluster analysis for a) pre-monsoon and b) post-monsoon season

\section{Cluster analysis}

Cluster analysis (CA) was computed to identify the similarity groups between the sampling sites. In pre-monsoon season (Figure 4a), Cluster 1 grouped less and unpolluted sampling sites. Cluster 2 related to moderately polluted sites whereas cluster 3 formed by the highly contaminated sites. Interestingly, post-monsoon season cluster analysis yielded two clusters namely; cluster 1contains less and moderately polluted sampling sites and cluster 2 is associated with highly contaminated sites (Figure 4b). It implies monsoonal influenced point and non-point source pollutant leaching process and groundwater flow ultimately expanded the polluted zone in post-monsoon season. The notable differences in the quality of groundwater between the sampling sites indicate possible land use influences. 


\section{Conclusion}

The groundwater quality of the Mettur industrial area is highly impaired as a result of unregulated manmade activities. Taking into account of the high concentrations of TDS, Cl, $\mathrm{Ca}, \mathrm{Mg}, \mathrm{Na}, \mathrm{PO}_{4}$ and $\mathrm{SO}_{4}$, the present situation imply serious risks to human health. Factor analysis suggested the disposal of industrial effluents; municipal sewage and agrochemical leaching are the major influencing factors of the ground water quality in the study area. In Cluster analysis, the notable differences in the quality of groundwater between the sampling sites indicate possible land use influences on water quality. The present study also stresses the importance of the periodical monitoring of the groundwater quality to assess the extent of pollution and other inhibitory chemicals which affect the groundwater resources in Mettur industrial region.

\section{References}

1. Murthy RK, Dhanakumar S, Solaraj G, Mohanraj R, Jawahar Raj R and Kumaraswamy K, Chinese J Geochem., 2012, 31(1), 015-023; DOI:10.1007/s11631012-0544-8

2. Ramachandraiah C, Centre of Economic and Social Science Studies, 2004, 56, 6-7.

3. Tank D K and Singh C C P, Nat Sci., 2010, 8(10), 1-7.

4. Ullah R, Malik RN and Qadir A, Afr J Environ Sci Technol., 2009, 3(12), 429-466; DOI:10.5897/AJEST09.031

5. Aboud SJ and Nandini N, Am J Environ Sci., 2009, 5(6), 678-687; DOI:10.3844/ajessp.2009.678.687

6. APHA, Standard methods for the examination of water and wastewater. $21^{\text {st }}$ Ed., American Public Health Association, Washington DC 2005.

7. Srinivasamoorthy K, Vijayaraghavan K, Vasanthavigar M, Chidambaram S, Anandhan P and Manivannan R, Arab J Geosci., 2012, 5(1), 83-94; DOI:10.1007/s12517-010-0162-x

8. De A K, Environmental Chemistry, New Age International, $4^{\text {th }}$ Ed., New Delhi, India, 2002.

9. $\quad$ Hussain M and Rao TVDP, Int J Adv Res., 2014, 2(2), 876-883.

10. Simeonov V, Stratis JA, Samara C, Zachariadis G, Voutsa D and Anthemidis A, Water Res., 2003, 37(17), 4119-4124; DOI:10.1016/S0043-1354(03)00398-1

11. Shrestha S, Kazama F and Nakamura T, J Hydro Inform., 2008, 10(1), 43-56; DOI:10.2166/hydro.2008.008

12. Kabata-Pendias A and Pendias H, Trace elements in soils and Plants, $2^{\text {nd }}$ Ed., CRC Press, Boca Raton, Florida, 1992, pp. 365.

13. Chen H M, Zheng C R, Tu C and Zhu Y G, Ambio, 1999, 28(2), 130-134.

14. Sharma RK, Agrawal M and Marshall F, Ecotox Environ Safe., 2007, 66(2), 258-266; DOI:10.1016/j.ecoenv.2005.11.007

15. Mortvedt JJ, Fert Res., 1996, 43(1-3), 55-61; DOI:10.1007/BF00747683

16. CGWB, District Groundwater Brochure-Salem District, Tamil Nadu, Central Ground Water Board, Government of India, 2008. 